\title{
Tiger-Hunting Scene on Yeh Pulu Relief in Bali. Romanticism of People's Heroism in the Study of Iconology *
}

\author{
I WAYAN ADNYANA \\ Faculty of Visual Art and Design, \\ Indonesia Institute of The Arts Denpasar \\ kun_adnyana@yahoo.com
}

\begin{abstract}
This article aims to analyze the tiger-hunting scene on Yeh Pulu relief, located in Bedulu Village, Gianyar, Bali. This relief is estimated to have been created by Balinese artists of the end of the era of Ancient Bali Kingdom in about the $14^{\text {th }}$ century AD. There are only few in-depth studies conducted on this monumental relief in the context of iconology by visual art researchers. Therefore, the author has conducted intensive field research and studies since a year ago based on Panofsky's iconology theory. Tiger-hunting is part of a series of scenes on the relief which in general tends to tell about everyday routines. The tiger-hunting scene carries an unusual theme amidst a wide range of Balinese cultural artifacts which tend to revolve around mythology and epics such as Mahabrata and Ramayana. Based on the theory of iconology which consists of a sequence of analyses starting from the pre-iconographic analysis, the relief characters were found in the form of rough sculptures on the surface of a rocky soil wall located near the Petanu watershed in Gianyar. The iconography aspects revealed that the characters on the relief figuration tend to be naturalistic; and iconologically, they tend to relate to the meaning of narratives on the romanticism of everyday heroism. Heroism nurtures the Balinese people's proletariat side in facing challenges in their life and the political power in the era of the Ancient Bali Kingdom.
\end{abstract}

Keywords: Iconology, Yeh Pulu Relief, Tiger-Hunting, and People's Heroism

\section{INTRODUCTION}

Yeh Pulu Relief is located in Bedulu village, Gianyar, Bali, Indonesia, about 35 kilometers to the north of Denpasar Municipality, the center of government offices of Bali Province. This relief is estimated to be carved in the $14^{\text {th }}$ century $\mathrm{AD}$. It has a length of 25 meters, and an average height of two meters.

This relief is unique in terms of media, techniques, and style of figuration. The sculpture medium is a steep cliff of stony soil. The sculpture

\footnotetext{
* This article translated from bahasa to English by Ni Luh Windiari.
} 
patterns tend to be rough and expressive compared to that on the reliefs of Borobudur and Prambanan temples in Central Java. Meanwhile, the style of the relief figuration looks very naturalistic. In terms of proportions, in addition to appearing to have a proper volume, the human figures also appear to resemble a normal size of adult humans.

Another uniqueness lies in the theme of the relief. Overall, the theme tends to describe daily activities. The theme is illustrated through a series of scenes, such as a scene of a man carrying a large earthenware jar containing arak (a special kind of Balinese farmer's wine), a scene of a man carrying a hoe, a scene of a tiger hunter, a scene of two men carrying a wild boar from hunting, and a scene of a man riding a horse. At the end of the relief scenes stretching from the north to the south (following the direction of the entrance stairs) there is a figure of Ganesha (without any detail of ornament sculpture).

Kempers, in spite of some doubts (due to several sentences ending with a question mark found in the text that he wrote), commented that the theme of this relief revolves around the heroism of young Krishna (Kempers, 1978: 136). Meanwhile, the author is more convinced that the theme of Yeh Pulu relief tends to revolve around the everyday heroism of ordinary people (Adnyana et al., 2017: 281).

In order to learn more about how ordinary people's everyday heroism is depicted in the relief, an in-depth study is needed on the prominent scene of the relief. For this reason, the 'tiger-hunting' scene is selected as the subject of the study.

\section{METHOD}

This study uses Panofsky's iconology theory, which consists of three levels of analyses (act of interpretation): pre-iconography (analysis of techniques), iconography (analysis of figuration styles), and iconology (analysis of intrinsic meaning) (Panofsky, 1971: 14). The three levels of analyses are conducted in sequence so as to form a series of positive syllogism starting from the results of the analysis of techniques to the results of the analysis of figuration styles, and to finally be able to find the meaning in the relief scene in question.

The pre-iconographic stage of analysis will result in a formal description relating to the description of the medium and the technique pattern. This first-stage analysis will lead to the interpretive description of the 
time (when the relief was made), the artist(-s) who made the relief and the prediction of the equipment used. Meanwhile, the second stage of analysis concerning the figuration style, will further strengthen the analysis of the three points referred to in the first stage of analysis, along with other explanations, such as that on the aesthetic concept (concerning the beauty element of the relief in question).

In addition, both stages of the analysis certainly include discussion on the other scenes on Yeh Pulu relief as an effort to deepen the analysis related to the figuration techniques and styles. Iconography is also concerned with finding allegory concepts and symbols in images (D'alleva, 2005: 22-23). It means that in the second stage of analysis, iconography also allows us to find patterns of narration and symbols which will then contribute to the meaning elements. Narrative patterns and symbols will enrich the discussion.

The third stage of analysis, which aims to find the meaning contained in the relief scene, will be developed with explanations related to the elements of the subject, the 'tiger-hunting' scene in question i.e. the tiger, hunters, and depiction of the supporting environment. As part of the effort to deepen the analysis and to be able to propose some examples related to the theme of the "tiger hunting" scene, this study also reviews some relevant literature, both in the form of painting and relief on various cultural artefacts. The comparative study conducted through the literature review aims to further sharpen the analysis that has been based on the syllogism of the first and second stages of analysis.

\section{DISCUSSION}

Kempers mentioned about Yeh Pulu relief in two books published in different years, namely: Ancient Indonesian Art (1959) and Monumental Bali (1978). In the first book, the "tiger-hunting" scene is described in one sentence which states that the scene is about a man attacking a tiger? (Kempers, 1959: 72). It is true that Kempers put a question mark at the end of the sentence which probably implied his doubt, but it is clear that the name of the animal written was tiger, not any other animal. However, in the book titled Monumental Bali, there was no mention of any tiger; instead, he argued that the animal was a bear as evident in his sentence, 'an attack of a bear?' (Kempers, 1978: 138).

The bear mentioned in the book Monumental Bali was also with a question mark at the end of the sentence. It is assumed that 'bear' was 
used to reinforce the interpretation that the "tiger-hunting" scene is a scene taken from the story of Krisna defeating a bear named Jambavat (Lohuizen in Kempers, 1978: 138). This means that the tiger mentioned in the first book that was later replaced by a bear in the second book was probably for the sake of a strategic effort to draw a relation as a basis of the interpretation of the story of Krishna that Van Lohuizen had pinned before which Kempers referred to. Thus, the idea does not seem to be based on a formal visual analysis of the relief, i.e. anatomical analysis of the formation and context of animal depiction in mimesis.

The fact that there were no bears living in the wild in Bali island makes it difficult to imagine that the Balinese artists who carved the relief tried to depict the bear in mimesis, considering that they had probably never seen it in person. It is in contrast to the sculpture depicting the movement of human figures that look clearly naturalistic because of the precision that makes it look like a normal human figure. Based on that explanation, a tiger is more likely to be depicted because the species had lived in the forests of Bali. In terms of the anatomy of the relief, the figure is more likely to depict a hairless tigress, with rounded ears and a rounded face (in contrast to bears characterized among others as having a long snout).

Furthermore, the relief medium is a cliff of hard stony soil. The relief has a length of 25 meters with an average height of 2 meters, and a carving depth of an average of more than 40 centimeters on a stony soil medium. For this reason, it was very unlikely that the medium was carved by a single person. The batu padas (stony soil) is more concrete and solid compared to the batu padas known today in Bali, collected from cliff walls along the rivers around Lodtunduh, Ubud or Blahbatuh village, in Gianyar. The stony soil used as the medium of Yeh Pulu relief is not only concrete and solid in nature, but it also has a rough surface (with many small grains of rocks as part of the stony soil layer). This surely made it more difficult for the artists in the carving process. For this reason, it makes sense that the carvings are expressive and rough, far from fine impression if compared to the reliefs on the Borobudur or Prambanan temples in Java. The chisel used was probably a metal chisel with a wide blade as there were not many intricate details produced.

The stone cliff used as the sculpture medium is located in the rice field area close to Petanu and Jurang rivers. It is very close to the archaeological site of Goa Gadjah in Bedulu, Gianyar, Bali. Looking at the location 
which is close to the rivers, it can be said that the existence of Yeh Pulu relief is closely related to the rock-cut Gunung Kawi temple located on the Pakerisan River in Tampaksiring, Gianyar, Bali (about $10 \mathrm{~km}$ to the north from Yeh Pulu relief).

Archaeologically, in Bali there are many views which suggested that Pakerisan and Petanu rivers were the centers of the civilization in the era of the Ancient Bali Kingdom, as evidenced by among others, the existence of Gunung Kawi temple which is known as the last resting place of King Anak Wungsu who ruled in Bali in the last quarter of the $11^{\text {th }}$ century (Kempers, 1959: 72).

The following analysis that can be proposed is that Yeh Pulu relief is a continuation of the aesthetics of the era of Ancient Bali, or the era before the Majapahit kingdom conquered Bali in 1343 AD (Krom, 1956: 220), such as the discovery of historical relics in the form of cliff shrines in Gunung Kawi and other cliff shrines around the Pakerisan and Petanu rivers. In terms of sculpture techniques, they are related to Yeh Pulu relief, which is also carved on a rock-cut cliff, instead of taking the hardstony soil to be carved in another location. This technique was barely found during the subsequent period governed by Majapahit rulers which reached its peak in the $15^{\text {th }}$ century under the rule of Dalem Waturenggong in Gelgel, Klungkung, Bali, which produced the aesthetics of wayang. Therefore, Kempers' argument that Yeh Pulu relief is a depiction of wayang figures carved on the cliff wall is not strongly supported by evidence (Kempers, 1978: 134).

\section{NOT WAYANG FIGURES}

The mention of wayang figures in the context of the visual iconography of Balinese art should refer to the pattern of stylized flat human figures as depicted in the Kamasan Balinese classical painting, which has developed since the $15^{\text {th }}$ century or an earlier wayang artefact in the form of a single god (Bhatara Guru) figure with four hands depicted with four halo (prabba) rays on a bronze inscription plate in Kehen Temple in Bangli, dated 1204 (Goris and Dronkers, 1955: 193).

In addition to having a flat depiction of human figuration (no element of perspectives and volume proportions), wayang stilization is also supported with clothing attributes and accessories as a symbol of status and identity of each figure, like the depiction of Bhatara Guru with four 
hands. Similarly, Krishna's portrayal in Kamasan painting is very clear marked by special crown attributes. The attributes identify the difference in the social class and the identity of the depicted figures (be they gods, knights, or commoners).

Looking at the two hunter figures on the tiger-hunting scene, it is clearly seen that they are two figures of commoners as they are barechested and wearing only a sarong wrapped around their waist as shorts. In terms of the proportion, the figures look naturalistic in that they appear to have a volume and realistic proportions with the physical features, i.e. a thin body, small thighs, and wavy hair without a crown. The hunter on the left side pulls the tiger's tongue, while the hunter on the right side pulls its tail. Each of the hunters' left hand is depicted as unsheathing a badik (a long dagger). Looking closely at the existing visual stylization, the scene is unlikely to be the depiction of the great God of Krishna, who is portrayed with a crown and usually with his chakra.

It is difficult to identify the two hunters' faces on Yeh Pulu relief as they are severely damaged. Whereas in fact, almost all the faces of the human figures are in a damaged condition, perhaps due to weathering or vandalism about which no experts could clearly explain. Thus, iconographic reading can only be done based on body characters, gestures, the clothes worn, weapons, accessories and other supporting subjects (depiction of plant tendrils, ornaments, etc.).

It means that based on the visual iconography analysis of the figuration of the two hunters, it is indeed more logical that the hunters depicted in the relief are commoners. Similarly, another hunter carved on the upper left corner or a little away from the fight between the two hunters and the tiger is also depicted lifting a badik-like weapon. Thus, it can be said that none of the three hunters can be clearly identified as the representation of God Krisna having a special attribute of Chakra. In wayang, badik (a long dagger) is commonly used by ordinary people.

\section{ABOUT THE TIGER}

The following analysis involves the interpretation of a tiger as a choice of representation. The tiger is one of the figures depicted in the relief scenes. The others are two men carrying a wild boar, a man riding a horse, and monkeys.

Yeh Pulu relief's scene sequence can at least be divided into two major narratives, one of which is the exterior narrative (outside the house or in 
the forest) including: a fragment of a prince riding a horse, a fragment of tiger hunting involving three people, a fragment of a man and a woman having a drink (indicated by a depiction of a earthenware water carafe emitting steam), a fragment of two men carrying a wild boar from hunting, and a fragment of a man riding a horse with the horse's tail being pulled by a woman (presumably a princess). It can be seen that the horse tilts its head up as if something suddenly stops it as it is just getting ready to run fast. At the end of the relief, the final fragment shows a figure of Ganesha which is very simply sculptured, with no ornamentation or any crown detail. At the southern end, two sculptured hermitage caves are seen, with a size of about 2x2x1.5 meters (Adnyana, 2017: 141).

Meanwhile, the interior narrative includes fragments where it begins with a figure of a man extending greetings (by raising his right hand), a man carrying a large earthenware jar on his shoulder, a figure of a princess, a figure of a priest (which looks very small), a figure of an elderly woman opening a door to a house, a figure of a man carrying a hoe, a figure of a middle-aged woman, and a figure of a demon-faced man sitting cross-legged (as if he was meditating) (Adnyana, 2017: 140). In all scenes in the interior narrative there is something like a long triangle-shaped roof, followed by a space without a roof with only plant tendrils carved.

In the analysis of the presence of a tiger as an animal for hunt, in addition to pointing out that this species of wild animals once lived in Bali forests, the analysis can also be developed by looking at world cultural artifacts related to the theme of 'a battle between a man and a tiger, or a man and a lion', such as an artifact depicting a battle between a man and a lion on a relief in Nineveh, Iraq carved by Asirian sculptors and dedicated to the King Assurbanipal in the $7^{\text {th }}$ century BC (Honour and Fleming, 1999: 109-110).

In one of the 68.6-centimeter-long reliefs, which is now in the collection of British Museum, London, there is a depiction of a battle between a king and a lion narrated in sequence. First, the lion is taken out of the cage by a guard, and then the lion jumps out, and gets ready to attack the king while the guards have been ready with their arrows drawn. In one section of the relief, there are three depictions of the same lion, the purpose of which is to describe the sequence of the story. The lion is used as an object to show the power of the king.

The choice of a lion or a tiger as an object is possibly based on the consideration that these animals are the symbols of the most powerful, 
ferocious, and deadly animals. A tiger or a lion is also commonly known as a symbol of the ruler or king of the forest. This means that the choice of a tiger as a battle object, may also represent the effort to show that humans are superior to the most vicious animals of any kind.

In the world history of human culture, in addition to a common depiction of a man fighting with a tiger, or a depiction of a man hunting a tiger, there is also a great deal of cultural wisdom that describes how humans and wild animals live in harmony. Anthropologist Danny Naveh mentioned in his study that in the Nayaka community, located in the south of India, when people are on their way to a forest, they always say (possibly with mantra) to the most vicious animals like lions, tigers, snakes and elephants, "You live in the forest and so do I; You come to find food, I come to find roots and tubers; I am not coming to harm you" (Naveh, in Harari, 2017: 88). It means that in the Nayaka forest community, human relationships with wild animals are maintained on the basis of the same interests over the forest, rather than annihilating each other.

On the other hand, the 'tiger-hunting' scene on Yeh Pulu relief is seen not entirely as a denotative fight between three hunters and a tiger, because when compared to the scene of the Assurbanipal King who is portrayed stabbing the lion with a dagger or an arrow, the two hunters on Yeh Pulu relief catch the tiger in a bizarre way, namely by pulling the tongue and tail of the tiger. Meanwhile, the badik (a long dagger) is unsheathed just to scare the tiger. There are no injuries seen on the body of the tiger.

\section{THE HUNTING TECHNIQUE HELPS FORM INTERPRETATION}

The next step of the iconography analysis is to find the meaning of the tiger-hunting technique on Yeh Pulu relief. It is obvious that the 'tigerhunting' technique is by pulling the tongue and tail of the tiger by two hunters. This technique is obviously illogical. It does not seem possible for a hunter to catch a tiger by pulling its tongue and tail. The tiger could attack the hunter or injure his stomach before he could do so. The tigerhunting techniques most likely practiced are among others the technique of hunting from a certain distance, either by using arrows, spears, or by jabbing a long dagger when a tiger tries to ambush and attack; instead of all of a sudden pulling the tongue and tail of the pointed teeth beast. 
It means that the depiction of the tiger-hunting scene on Yeh Pulu relief tends to be connotative rather than realistic, or it may even be hyper-realistic. The interpretation of this tiger-hunting scene may give rise to multi-layered meanings. Two different interpretations may present contradictory meanings, or they may even present meanings that can be combined to deepen the analysis to find more coherent meanings that complement each other, although they are not a single meaning.

This super/hyper-realistic battle scene between men and a tiger does not refer to a real-photographic depiction of a tiger and men, but rather to comment on the exaggerated pattern of representation of the tigerhunting technique, indicated by the depiction where the hunters pull the tiger's tongue and tail with bare hands. This scene does not adopt a usual way of tiger-hunting techniques, i.e. using arrows, spears or daggers. The depiction of the hunters catching the tiger by directly pulling its tongue and tail, is a kind of symbolical representation aiming to increase the power of humans as a superior and skillful hunter/conqueror. In further contexts, it may be to show men as the center of strength and brilliance.

The hyper-realistic representation causes the unusual tiger-hunting method or technique to look reasonable and common. The people observing the scene may be amazed at the almost realistic way of representation and ignore the possible connotative meaning hidden in the representation of the tiger-hunting scene.

In a connotative context, the tiger-hunting technique with bare hands will refer to analogical or metaphorical narratives beyond usual hunting techniques. The tiger in the scene only serves as a symbolic representation, not the real beast itself. Tigers may simply serve as a symbol of power. It might have symbolized the political power that threatened Bali, or at least disrupted the harmony of the people of the end of the era of the Ancient Bali Kingdom.

\section{PEOPLE'S HEROISM NARRATIVE}

The presence of a tiger does not refer to the notion of a certain power (either political or military force) that can be traced explicitly. Rather it becomes a series of puzzles that allows for interpretation to be directed to a political map that is close to the era when Yeh Pulu relief was created.

Referring to the pre-iconographic analysis, which among others includes the analysis of the relief medium, i.e. a living rock cliff using a 
direct carving technique on the rock-cut, there is a similarity in terms of the medium and carving techniques applied with that on the Gunung Kawi Temple in Tampaksiring, Gianyar, Bali. The Gunung Kawi Temple is estimated to have been constructed in the $11^{\text {th }}$ century as a final resting place for the family of the Ancient Bali Kingdom, one of whom is King Anak Wungsu (Kempers, 1959: 72). This means that Yeh Pulu relief is more likely to be the legacy of the era of the Ancient Bali rather than by the subsequent rule, namely the Majapahit in Gelgel, Klungkung, which reached its peak under the reign of King Dalem Waturenggong in the $15^{\text {th }}$ century.

The second reason is the fact that Yeh Pulu relief was only discovered in 1925, by painter Niewenkamp, who heard the news from farmers around the artifact Gua Gadjah, which was also confirmed by Ubud Palace at that time. Although the people probably knew about the existence of the relief, the relief was at least not as maintained as it is now. Some parts were covered by shrubs and soil, and some surface of which was passed by water run-off, because before the conservation of the relief, there were plots of wet rice fields on the location. This means that if the relief was a relic of post-reign of the Ancient Bali Kingdom, it would undoubtedly be well maintained, just like Gelgel relics in general that remained maintained or used to be part of customary and religious activities.

Thirdly, Yeh Pulu relief is located around the Pakerisan River, in Gianyar. While it is clear that artifacts constructed along Pakerisan River and along the Petanu River are sites under the rule of the Ancient Bali Kingdom, it then makes sense that Yeh Pulu relief located around the Petanu and Jurang rivers, is also part of the kingdom.

Based on these three reasons, it can be emphasized that Yeh Pulu relief was carved in the end of the era of the Ancient Bali Kingdom in about the $14^{\text {th }}$ century, which implicitly denotes Bali's opposition against Majapahit's political power, particularly reflected in the tiger-hunting scene on Yeh Pulu relief. The tiger tends to ultimately serves as a symbolic-metaphoric representation of the great political power (whether it be the deception of power or the invading forces) entering Bali at that time.

Many written pieces of historical evidence tell us that the Majapahit Kingdom employed various ways in its effort to conquer and unite small 
kingdoms in the archipelago under its power, be they diplomatic, cultural dialogues, political tactics, or invasion. The conquest of the Ancient Bali Kingdom, which at that time was ruled by the last king Sri Asta Ratna Bumi Banten, was with the tactics of political deception and through the invasion of Majapahit troops from the north and south of Bali. Gadjah Mada's victory in leading Sedang and Bali wars was evident in the inscription of Majapahit's maha patih (Prime Minister) Gadjah Mada. It was reported that the king of Bali and his army were killed during the invasion of Majapahit Kingdom to Bali in 1343 (Krom, 1956: 220-221).

It seems that Yeh Pulu relief was carved in the era of war between Bali and Majapahit. This relief can then be understood as a marker that provides a symbolic testimony of the patriotism of the Balinese people as depicted in various manuscipts on the courage of the army of the Ancient Bali king in defending the kingdom, before they finally had to flee to the hilly areas of Bali (Warna et al., 1986: 127-128), as the plains and coastal areas of southern Bali had almost all been defeated by Majapahit starting from the mid of the $14^{\text {th }}$ century.

The tiger-hunting scene depicting the unusual tiger-hunting technique by pulling the tiger's tongue and tail with bare hands signifies that the power consists of political tactics and anger. Tigers in real, show their power with by roaring and they show their anger and power by lifting their tail high. The scene symbolically-metaphorically signifies a great political power that is developed and continued surprisingly through tactics in using ideological discourse, issues and language, and by showing the power by gathering as many soldiers as possible.

The tiger-hunting technique provides a symbolic lesson, that in order to resist such great political power, one must use an equally strong ideological discourse and language, as well as a ranks of equally valiant and patriotic army troops. A tiger's roaring voice would be inaudible if the tongue was forcibly pulled away, and it would not be able to jump and attack if its tail was strongly pulled. This is a symbolical-metaphorical description of the strategy in the war against political power.

The attack in the context of the 'tiger-hunting' scene is not performed by a crown prince or king but by common people. Common people represent the image of heroism with no strings attached. They are just involved in war to fight against absolute political power, because absolute power tends to be authoritarian and corrupt. The common 
people can also represent that the ideological discourse and language that are always superior are the ones which stand for universal humanity, so is the most superior military technique, the army of the people, which makes the sense of heroism as the lifestyle of all the people.

\section{CONCLUSION}

Based on the stages of analysis that have been explained in the discussion, the tiger-hunting scene on Yeh Pulu relief proved to have a very important historical meaning and socio-spiritual significance. The historical meaning is seen in the use of hard stony soil wall as a medium, and the technique of direct rock-cut carving which clearly indicates the era when the relief was carved, i.e. the era of invasion of Majapahit Kingdom to the Ancient Bali Kingdom in about the mid of the $14^{\text {th }}$ century AD. The use of hard stony soil, a cliff wall and a direct cutting technique (rock-cut) clearly shows that this artifact is a continuation of Ancient Balinese aesthetics, as seen in relics of Gunung Kawi Temple in Tampaksiring, Gianyar, which was built during the reign of the $11^{\text {th }}$ century Ancient Bali Kingdom under King Anak Wungsu.

The following proof which reinforces that Yeh Pulu relief is a continuation of the aesthetics of Ancient Bali, also concerns the location of the artifact, i.e. on the cliff, on the paddy field between Petanu and Jurang rivers. Petanu and Pakerisan rivers are the centers of the ancient Balinese civilization era, proven by many relics of cliff temples, caves and hermitages found around the areas. The location is very far from the central government of Bali in the era of the invasion of Majapahit, namely in Gelgel, Klungkung.

The figuration style of the tiger-hunting scene which tends to look realistic with a simple depiction, makes it clear that the claim saying that Yeh Pulu relief is a wayang relief, is inaccurate due to the weak bases of arguments. Wayang (puppet) figures are normally depicted as flat figures with almost standard stylization patterns, including the use of crown, clothing, and accessories to show the identity and role of each puppet figure. The tiger-hunting scene is far from such visual criteria. The tigerhunting scene is more dynamic, with the presence of three hunters who signify the figure of ordinary people. 
The tiger-hunting scene carved in the depiction of an unusual hunting technique is clearly a symbolic representation, pointing to the heroic narrative of the Balinese people against the invasion of Majapahit in the mid of the $14^{\text {th }}$ century. The tiger-hunting technique depicted through the pulling the tiger's tongue and tail using the two hunters' hands simultaneously, tends to denote a connotative message, where the tiger's tongue means the power of discourse (the strategy of political ideology) while the tiger's tail means a strong soldier (people's solidarity). Both symbolically represent the power of the state to seek victory. Both can be defeated by people's solidarity and resistance, by constructing an ideological discourse and a solid military motivation.

The tiger-hunting scene on Yeh Pulu relief in Bedulu, Gianyar became a historical marker and a symbolic representation of Balinese people's patriotism in fighting against the invasion of Majapahit Kingdom. Certainly, the existence of Yeh Pulu relief with a series of narratives carved on it, is always interesting to be continually studied, either on the pattern of meaning of each or overall scenes/plots, and it will undoubtedly benefit the academic community if the effort to re-interpret this ancient artifact of Balinese culture is continued.

Acknowledgements: This article is a part of research grant, scheme name: Penelitian, Penciptaan, dan Penyajian Seni (Research, Creation, and Presentation of Arts), was supported and funded by Ministry of Reseach, Technology, and Higher Education of the Republic of Indonesia, 2018, and therefore I would like to extend my gratitude and appreciation to them. Research members: Ni Luh Desi in Diana Sari and Anak Agung Gde Rai Remawa (photographer, layout desaign, data collector).

\section{References}

Adnyana, I Wayan, "Creative Contemporary Painting: Based on Iconography of Yeh Pulu Relief", proceeding of the $2^{\text {nd }}$ Annual of International Interdisciplinary Conference of Arts Creative and Studies (IICACS) (14-15 October 2017), Donie Fadjar Kurniawan (editor), Surakarta: Institut Seni Indonesia (Indonesia Institute of Arts Surakarta), 2017: http://repo.isi-dps.ac.id/2454/.

Adnyana, I Wayan, et al., "Exploring Yeh Pulu Relief: An Iconography Approach". Jurnal Seni Budaya Mudra 32(3), September 2017: http://jurnal.isi-dps.ac.id/index.php/mudra/article/view/176.

D'Alleva, Anne. (2005), Look Again! (Art History and Critical Theory). New Jersey: Pearson-Prentice Hall Inc, 2005. 
Goris, R. and P.L. Dronkers. Bali Atlas Kebudayaan: Cults and Customs Cultuurgeschiedenis in Beeld. Jakarta: Indonesian Government, 1955.

Harari, Yuval Noah., Homo Deus: A Brief History of Tomorrow. London: Vintage, 2017.

Honour, Hugh, and John Fleming., A World History of Art, Fifth Edition. London: Laurence King, 1999.

Kempers, A.J. Bernet. Ancient Indonesian Art. Cambridge, Massachusetts: Harvard University Press, 1959.

Kempers, A.J. Bernet. Monumental Bali. Den Haag: Van Goor Zonen, 1978.

Krom, N.J., Zaman Hindu (the second printed edition), translated from De HindoeJavaanche Tijd, translated by: Arif Effendi. Jakarta: P.T. Pembangunan, 1956.

Panofsky, Erwin., Studies in Iconology. Corolado: Icon Edition, 1971.

Warna, I Wayan, et al. (Team of Translators), Usana Bali Usana Jawa (Teks dan Terjemahan). Denpasar: Department of Education and Culture of Bali Province, 1986. 